\title{
7
}

\section{Small gestures in a big world: The Hague 1869}

Karl Baedeker's travel guide to Belgium and Holland said of The Hague that Nno other Dutch city had so many pretty, broad streets, tall stately homes and large open squares. ${ }^{1}$ A person who had not visited any other major European city might well think that The Hague was a resplendent place, comparable to the grand capitals of nineteenth-century Europe. But people arriving from Paris, London, St Petersburg, Vienna, Brussels, Rome or Berlin - like the foreign guests of the seventh international statistical congress - would have thought they had landed in a provincial town. The city centre must have made a modest, even small-town, impression. According to the census conducted at the end of 1869, The Hague had a population of just over 90,000 , far less than the cities where the congress had been held before.

You could walk across the entire city in a good quarter of an hour. In those days, Hollandsche Spoor railway station lay outside the city limits. One side of Stationsweg, the road that ran straight to the city centre from the station, offered 'a free and unobstructed view ... charmingly alternated with tastefully planted pleasure gardens, straight leafy lanes, fertile orchards and opulent fields, ornamented with handsome, gambolling livestock.' ${ }^{2}$ So much green in and around the city was an important feature of the urban landscape at a time when the pleasure of the respectable bourgeoisie depended on beauty, refined entertainments and fresh air. The Hague was the appropriate setting for the seat of government of a nation that proudly displayed its conventionality and self-restraint, preferably within view of the neighbours. Anno 1869 the city was worthy of its stately full name, 's-Gravenhage.

The population of The Hague grew steadily throughout the first half of the nineteenth century, not because local trade and industry had any particular pulling power but because of the influx of civil servants, diplomats and servants of the Royal Household. From 1830 onward, the government was no longer 
divided between The Hague and Brussels, so the Royal Household and the government bureaucracy were moved to The Hague permanently. Until well into the second half of the nineteenth century, newcomers were able to find homes within the old city limits. With the construction of the Willemsparkbuurt and Stationsbuurt districts in the 1860s the city began a conservative expansion, initially only for the benefit of the wealthy. There was certainly nothing comparable to the spate of demolition and construction in many other European cities. At the time of the congress, a national monument - Batavia with a flag, a sheaf of arrows and the Dutch lion at her feet - was under construction on Plein 1813. It was the only structure in the city that was in the same league as the architectural and sculptural lieux-de-mémoire being erected in the countries neighbouring the Netherlands. No one had yet heard of the young Vincent van Gogh, who was hired for a position at The Hague branch of Goupil \& Cie art dealers in 1869.

The social programme for the congress was in keeping with the entertainment conventions of the upper middle class: a visit to the zoo founded in 1863, free admission to the local museums (including the temporary exhibition of the Red Cross in the drawing academy building on Prinsessegracht), admission to gentlemen's societies like De Witte and the Besognekamer (when in female company, the conferees repaired instead to the Tent, an establishment in the Haagsche Bosch, a wooded parkland in the city), an evening concert in the Haagsche Bosch, dinner at Badhotel at the beach in Scheveningen and an excursion to Amsterdam by chartered train. It is remarkable how accommodating the programme, even the official part, was to women. The congress newsletter reported that a large number of ladies had attended the ceremonial opening of the congress in the Ridderzaal (Knights' Hall). The members of the congress would have had to order tickets for them in advance. 'Unaccompanied' women were not welcome everywhere, and when women were unchaperoned they had to make it blatantly obvious that they had no improper intentions. ${ }^{3}$

The Hague was modest in its hospitality, as a correspondent remarked: 'The city does not have a festive appearance, as it did during the literature congress, the marksmen's' congress and the official welcoming of The Hague's victorious marksmen.' But that was no great matter: '... the statisticians have not come to make merry and most of the local inhabitants understand little of what the gentlemen have come to do. ${ }^{4}$ We must count King Willem III among 'most of the local inhabitants', as he had no interest whatsoever in the congress or its participants. In the monarchical states that had hosted previous congresses, members of the royal house had put in an appearance. Willem III, known for his occasional breaches of decorum, had absolutely no desire to attend the statistical congress. The rules of international courtesy, though, required him to grant an audience. The reception he hosted at Noordeinde Palace interrupted the opening session on Monday 6 September. The king received his guests at one o'clock, but disappeared not ten minutes later, having spoken to no one. The official chairman of the congress, the energetic minister of the interior Cornelis Fock, later wrote that the king's behaviour 'did not leave the delegates with a 
favourable impression'.

The subsequent reception at Huis ten Bosch, Queen Sophie's summer residence, was quite different. She 'spoke to most individuals in their own language about their field of study and the interests of their country'. The audience lasted for over an hour and was highly appreciated by those present. Sophie announced later that she hoped to attend a few of the sessions. The next day the conferees had an opportunity to pay their respects to the Prince of Orange, the honorary chairman of the congress, but he had no more time for the guests than the king. Fock - a liberal - decided that the Family of Orange had cut 'a pathetic figure in the presence of the foreigners. ${ }^{5}$

The plenary sittings took place in the Ridderzaal, better known at the time as the Loterijzaal, the office of the national lottery. The renovations carried out by Willem Nicolaas Rose, the government architect, in 1861 had done nothing to improve the hall, at least not in the opinion of the public press. Replacing the wooden coping with a cast-iron structure was seen as the ultimate manifestation of the 'artifice of faux Gothic.' ${ }^{6}$ Moreover, the rest of the building was left in a pitiful state: 'The decaying and grimy condition of the building is a vexation for many, and now on this occasion when so many distinguished foreigners are to be received, they thought to beautify it by sweeping the exterior stair, repairing a few broken panes and hanging a new, peculiarly-shaped oak door.'

The sessions were held in the rooms surrounding the chamber of the Tweede Kamer, the lower house of parliament, and the pre-congress meetings took place in the hall of the 'Vereeniging' on Willemstraat. A 'highly remarkable exhibition of statistical maps and drawings and a collection of books by Nijhoff were assembled together' in the antechamber of the Tweede Kamer. The local correspondent mentioned above, who mingled with the statisticians, observed that there were 'so many decorated - and such abundantly decorated - gentlemen. ${ }^{8}$ What he did not know was that every host country, where the custom existed, had conferred honours on the conferees on a large scale, which meant that each of the congress veterans had a whole collection of medals.

\section{The two faces of Dutch statistics}

Simon Vissering and Marie Matthieu von Baumhauer were familiar faces to the regular participants of the international statistical congress. After the death of Jan Ackersdijck in 1861, they became the torchbearers of Dutch statistics in Europe. The Dutch government had good reason to put Vissering and Von Baumhauer in charge when the congress came to The Hague. Vissering was acting chairman of the preparatory commission and Von Baumhauer was responsible for organisational matters. They knew each other from various learned societies and had served together on the Rijkscommissie voor Statistiek (State Commission for Statistics, 1858-1861), a failed attempt to establish a permanent central commission of scientists, scholars and civil servants in the Netherlands, as recommended by the congress. 
Vissering distinguished himself as a liberal thinker well before the political revolution of 1848. He was involved in the founding of the Amstel Sociëteit, the precursor of the liberal party in the Netherlands. Von Baumhauer belonged to a group of liberal reformers intent on improving the moral condition of the nation. He and Willem Hendrik Suringar established a Dutch agricultural colony in the manner of Mettray and participated in the first prisons congress of 1846 in Frankfurt. ${ }^{9}$

It is difficult to tell whether Vissering and Von Baumhauer got along. They shared a fundamentally liberal mindset and a passion for statistics, though their opinions about nature and method differed at times. This had more to do with the nebulous state of the science than with any deep intellectual differences they may have had. Where Vissering and Von Baumhauer differed most was in their professional background: Vissering was a law professor and Von Baumhauer was a civil servant at the Ministry of Foreign Affairs, where he served as director of the statistics department established in 1848. They were dependent on each other because statistics had never been an exclusively state affair in the Netherlands. Given his subordinate position at the ministry, Von Baumhauer was unlikely to ever become the Netherlands' undisputed senior spokesman for statistics, like Engel in Prussia or Czoernig in Austria. Vissering was repeatedly rebuffed in his attempts to improve the way statistical inquiry was organised in the Netherlands, as evidenced by the dissolution of the Rijkscommissie in 1861. Together they had more leverage than on their own.

Until the Centraal Bureau voor de Statistiek (Central Statistics Office) was established in 1899, Dutch statisticians had been virtually ignored by government. Admittedly, some ministries had departments that conducted counts, but without any efficient coordination. Throughout the nineteenth century, various statistical bureaux, departments and commissions came and went, none of them surviving for very long. A unique state tradition of strategic restraint and deliberate intervention was part of the reason why efforts at institution-building consistently failed. The Netherlands was not a weak state but rather an accommodating one, which steered a middle course between concession to social forces - the legacy of the Republic - and a strong tendency towards organisation, a Batavian-French impulse. Statistics flourished under both approaches, though in different ways. Vissering and Von Baumhauer represented the two organisational structures of statistics in the Netherlands: one shaped by the state and the other supported by society's elites.

Without denying the pre-revolutionary roots of statistics, it can be said that the Batavian-French Revolution ignited the development of government statistics. ${ }^{10}$ Once the organs of public administration and, to a lesser extent, parliament had sampled the benefits of statistical information, they could no longer go without. What had been introduced in the Batavian-French period survived in one form or other after 1815 . That is to say, the statistics remained, but organisation and methods of collecting data tended to change. The political climate was not conducive to increasing and centralising statistical activity within the government bureaucracy. A powerful central statistics bureau would 
have been inconceivable immediately after 1815 . The spectre of French centralisation haunted those in power and public opinion. Nevertheless, the provincial agriculture commissions continued to submit their annual statistics report to the ministry. Charity boards, provincial executives and school inspectors continued to write their reports on poor relief and education. And with conscription in force, municipalities kept up-to-date statistics on residents who were eligible for military service.

There were two problems impeding the usefulness of all these figures: insufficient systematisation and a lack of openness. If both were to be dealt with, government statistics would at a stroke meet the criteria that Gijsbert Karel van Hogendorp had formulated back in 1819 regarding the necessity of good statistics: publicity, participation and an informed public opinion. There was also some pressure from the academic world - specifically from Hendrik Willem Tydeman (the translator of Schlözer's Theorie der Statistik) - to lift the veil of secrecy shrouding statistics.

In 1826 the regime of King Willem I responded to their call by establishing a statistical bureau and a commission. This small but specialised system began as an energetic operation (see Chapter 1). With specialists like Édouard Smits, Rehuel Lobatto and the young Quetelet collaborating, it seemed as if government statistics in the Low Countries had carved out a niche for itself. The census of 1829 was an impressive achievement. But with Belgian independence and the subsequent brain-drain of prominent statisticians, statistical activity at the central government level in the Northern Netherlands virtually ground to a halt. It was as if the Dutch government wanted to differentiate itself from the Belgian government, which was directly involved in statistical activity.

So, once again, it was up to the academic elite and the provincial and local authorities to keep the fires burning, a difficult task at best. Only after the political sea change of 1848 was there scope for setting up a new statistical bureau. Johan Rudolph Thorbecke, the new Prime Minister and Minister of the Interior, had taught statistics for two decades as a professor of law. He was not fond of 'arithmeticians' like Quetelet but, like most liberals in Europe, believed that statistical information was essential for public administrators and citizens. Von Baumhauer was put in charge of the bureau, which was made an autonomous department in 1857. In 1849 Von Baumhauer published an article in De Gids, in which he laid out the function of statistics. He defined statistics as the science of reality, which attempts to express in numbers that which has come to pass. ${ }^{11} \mathrm{He}$ was obviously not considered to be an 'arithmetician' of the kind so loathed by Thorbecke (who would never have employed such a person at his ministry). Statistics, Von Baumhauer continued, 'is not about theory, but about practice and history. This was, of course, a sensible point of departure for a civil servant. Furthermore, he stressed how powerful statistics ('the truest friend of humanity') was, despite the apparently weak position it had occupied for nearly two decades: 'No individual, however inconsequential in influence and power, can elude statistical inquiries. From the moment he first sees the light of day, statistics confers on him a place in the record of births.' Von Baumhauer then 
demonstrated how many times in a human life statistics registered an individual's actions, concluding in an almost threatening tone: 'Statistics does not leave he whom it recorded in its registers on the first day of his life to his death bed without one last time chronicling the terminus of a full course of life and the hour of death.'.12

Soon after the Netherlands had undergone far-reaching constitutional reform in 1848, Jeronimo de Bosch Kemper began publishing an annual entitled Staatkundig en Staathuishoudkundig Jaarboekje. He continued in the same vein as Tydeman and Van Hogendorp and emphasised the voters' obligation to stay abreast of what was happening in the country with the help of statistical information. Various associations, such as the Provinciaal Utrechts Genootschap voor Kunsten en Wetenschappen (Utrecht Provincial Society of Arts and Sciences), the Nederlandsche Maatschappij tot bevordering der Geneeskunst (Netherlands Medical Society) and the Landhuishoudkundig Congres (National Agriculture Congress), pressed for a statistical society, modelled on the Statistical Society of London.

In the same volume of De Gids in which Von Baumhauer published his defence of statistics, Vissering wrote a searing piece about the necessity of promoting statistics in the Netherlands. Openness was his guiding principle, too: 'The time of secrecy in state government is over; the altered structure of our public institutions compels the government to greater openness and the nation to cognizance. Statistics is the foundation of that openness, and as each day passes the need for statistical information will be felt more and more strongly.'13 Universities were urged to present the discipline of statistics more distinctly, and the government to make funding available for that purpose, but also - primarily - for the establishment of an independent statistical bureau. The first task the bureau should undertake was the compilation of a comprehensive Statistiek des Rijks (Statistics of the State). In the meantime, Thorbecke had set up a statistical bureau at the ministry, but it met only a few of Vissering's criteria. In 1857 Vissering managed to consummate his plan for a Vereeniging voor de Statistiek (Statistical Society) which in 1862, after the Rijkscommissie proved unviable, functioned as a kind of central statistical commission.

Yet, Dutch statisticians were not entirely satisfied. Though they enjoyed a good reputation internationally and were always prominently represented at the international congress, they were unable to implement important decisions adopted by the congress, especially those relating to organisational matters. When, in 1863, Vissering looked back at his own article in the Gids of 1849, his optimism was measured. The number of statistical documents issued by both the Vereeniging voor de Statistiek and the government had increased significantly, but the loss of the Rijkscommissie after just three years was a serious setback. Vissering, who had served as acting chairman of the Rijkscommissie for a time, blamed the failure on two problems, one being geography - the members had to travel from all over the country to attend the meetings - and the other, parliament's lack of appreciation for statistics. 'The only possible result of parliament's precipitous decision [to abolish the Rijkscommissie],' Vissering 
wrote with foresight, 'is that this country will be without an effective arrangement for statistics for a very long time. ${ }^{14}$ From our vantage point, we can see that they continued to deliberate about an effective arrangement, but decades would pass before it came to fruition.

\section{Idées-mères}

Vissering and Von Baumhauer had vast experience of Dutch and European statistics by the time they were asked to organise the seventh international congress. Both men were members of the state commission set up at the end of 1868 to plan the congress. In addition, several members of both houses of parliament, the Raad van State (Council of State) and other government institutions joined the preparatory commission. In January 1869 the commission's ranks were expanded with the addition of another ten people, most of them professors and senior civil servants 'whose help and advice on the development of a programme for the congress' were considered essential. ${ }^{15} \mathrm{~A}$ few more secretaries were brought in as time grew short. The organisers were given a total budget of 20,000 guilders for the congress.

Much of the brainpower came from Von Baumhauer, who presented the preparatory commission with an Idées-mères, a grand scheme encompassing organisational matters and congress topics. Following the example of Engel and Maestri, who had compiled an overview of topics treated by previous congresses, Von Baumhauer wrote a reasoned commentary on what had gone before, accompanied by suggestions for further discussion. His plan had two main objectives. The first was to enhance the international character of the congress. In Florence, nine in ten participants had been Italian, while about half the conferees in Brussels and Paris had been foreign. Von Baumhauher wrote in his epilogue that the grandest idea of all was the 'denationalisation' of the congress. ${ }^{16}$ Secondly, he favoured limiting the number of sections to ensure there would be time to address the items on the agenda thoroughly and avoid fragmenting the expertise. He proposed five themes: methodology, statistics of the justice system, financial statistics, fisheries statistics and statistics of overseas territories. With the latter two, he obviously intended to incorporate specific Dutch interests into the programme.

Von Baumhauer believed that this configuration would increase the effectiveness of the congress. The role of the official representatives would also need to be enhanced. As suggested earlier by the Danish statistician Christian David, the representatives would stay on for a few days after the congress to go over the section and plenary reports and distil the information into final decisions, which they would then present to their respective governments. They could expect their decisions to be received favourably and constructively only if there was uniformity in the organisation of government statistics. Von Baumhauer endorsed the proposal about streamlining national statistics put forward by Pietro Castiglioni in Florence, which until then had been ignored. There were 
also several practical matters, such as franked international mailings of statistical publications, which had yet to be arranged.

In the introductory section on methodology, Von Baumhauer reiterated his vision on statistics, showing himself to be a faithful adherent of Quetelet. $\mathrm{He}$ emphasised the close relationship between statistics and legislation: 'A lawmaker without statistics is like a steersman without a compass; a statistician who knows nothing of the law and nothing of national customs is like a man in a rowboat on a desolate coast without lighthouses. ${ }^{17}$ It was vital to have knowledge of differences and changes in legislation in order to make accurate interpretations. The figures for stillbirths or children born out of wedlock, for example, could vary widely from country to country for the simple reason that the phenomena were defined differently. Von Baumhauer also asked his audience to give special attention to the subdivisions of statistical categories. Borrowing from Quetelet, he said 'The more subcategories there are, the closer one comes to identifying the cause. ${ }^{18} \mathrm{He}$ also shared Quetelet's interest in numbers, tables and mathematical calculations. He even adopted Quetelet's position on probability - that it should receive more attention at the congress - though he knew this was a controversial issue. It is very likely that his stance was connected with a dual desire to limit the number of outsiders and build a bridge between statistics and actuarial mathematics. Moreover, the theory of probabilities was for Von Baumhauer to return to the foundations of nineteenth-century statistics, the theory of constants and the law of periodicity, i.e. the idea that all manner of natural and social phenomena increase and decrease according to fixed patterns.

The next proposal concerned judicial statistics, an area of inquiry that served administrative interests, but also provided insight into a country's moral condition. Quetelet owed his fame to his analysis of criminal tendencies, based on crime statistics gleaned from court records in various countries. However, national differences in legislation tended to restrict comparative statistical inquiry. Existing statistics on civil law and commercial law - the two areas Von Baumhauer wished to concentrate on - were a mixed bag, though this subject had been on the agenda at the congresses in Paris, Vienna and London. By way of illustrating the importance of this topic, he talked about the consequences of the surge in international migration. Marriages between people of different nationalities were becoming much more common, but the legal ramifications were virtually unknown. Statisticians could help map the differences between countries in order to bring lacunas to light more quickly to facilitate a system of 'best practices'.

The third theme, financial statistics, had been treated exhaustively at the Vienna congress in 1857, but few concrete results had been achieved in international statistics. Von Baumhauer unleashed such a barrage of questions his audience must have wondered whether it was possible to make any progress at all in this area.

Fisheries statistics was the fourth topic. Various North Sea countries had hosted international exhibitions on fishing methods and fish products. It was 
thought that the statistics of offshore and river fishing would provide valuable information about the most effective fishing methods. This subject was also important for regulating fishing areas.

The final major topic was the statistics of overseas territories. Von Baumhauer admitted that he was not a specialist in this area. One of the more important objectives of this type of inquiry was to obtain information regarding the revenues of the system of forced farming in the Dutch East Indies. Remarkably, his overview contained hardly any references to existing colonial statistics of other countries, though the London congress of 1860 had introduced this issue.

The commission which was in charge of preparing the congress, attempted to shape the programme along the lines set out by Von Baumhauer. The precongress of official representatives addressed just three topics: the congress's decision-making process, the rules of procedure and franked mailings of statistical publications. Only the first topic was likely to arouse disagreement, since it was related to the overall organisation of the congress. One of the questions that had to be resolved was whether every invitee was permitted to vote on resolutions. Professional statisticians were growing more concerned that the congress would lose influence if every interested person had a vote. As we have seen, in Florence the invitees included several hundred Italians, many of whom were not well versed in national statistics.

With regard to the rest of the programme, too, the preparatory commission built on Von Baumhauer's Idées-mères, completing it with commentary provided by Dutch and foreign experts. Vissering, who had been teaching statistics as part of the law curriculum at Leiden University since 1850, was eager to join in the ongoing debate about the nature of statistics as a science. Like the lecturer he was, he systematically recounted the different movements that made up the multifaceted field of statistics. Statistics intersected with other areas of scholarship such as history, geography and ethnography and various natural sciences, but ultimately it was an independent discipline. He compared statistics to Proteus, the son of Poseidon, who had the power of prophecy but assumed different guises to avoid being asked to tell the future. Vissering agreed with Moreau de Jonnès, who had said: 'Statistics is the science of social facts, expressed in numerical values. ${ }^{19}$ But like so many who wished to have the last word about statistics as a science, Vissering did more to increase the confusion than to resolve it, as the ensuing discussion would reveal.

Von Baumhauer sought a path to consensus. With his essay on the methodology of statistics, he hoped to foster solidarity among professional statisticians by appealing to them at the level of their technical, practical capacities. However, his remarks were as incisive as Vissering's. Von Baumhauer believed that methodology was a cover for the problem of defining statistical categories. $\mathrm{He}$ showed that official statistics commonly lacked empirical rigour because of the haphazard way in which categories were defined. For example, the German states divided up the population into age groups for no other purpose than to show how many people were available for military service. There were various subcategories for men aged 14 to 60 , but not for women in the same age group, 
which made it impossible to do other kinds of analysis, for example comparing the age distribution of the population with mortality tables. An ordinary civil servant could simply rearrange figures and units that had been defined in advance, while a civil servant specialising in statistics would first need to have detailed knowledge of the material in order to present the figures in the best possible light. For that reason alone, Von Baumhauer argued, a central commission was needed to provide scientific oversight.

Von Baumhauer continued in this vein, using the seemingly undisputed topic of methodology to put forward his ideas about accuracy. He proposed to minimise the number of subjects that could be investigated in a single statistical inquiry: 'The more we ask, the more likely it is that inaccuracies or lacunas will occur in the answers to each question. ${ }^{20}$ He had a strong aversion to simultaneous counts of population, livestock, agricultural production and industrial production. Moreover, he claimed that it was not just necessary to differentiate by subject, but also by season so that data about specific topics could be collected at the proper time. Occupational surveys would be more accurate if they took more account of the possibility that members of a single household might have different occupations. Precision was possible only if statisticians counted exactly what was meant to be counted, no more and no less.

For the same reasons Von Baumhauer also favoured restricting the scope of statistics. The mere fact that a phenomenon was quantifiable did not make it a legitimate object of statistical inquiry. Only the very best statisticians - giants like Humboldt and Quetelet - were capable of integrating the natural sciences into statistics. Von Baumhauer believed it was more realistic to limit statistical inquiry to matters pertaining to the physiology of human beings and society. After all, he argued, in the natural sciences a law is the point of departure and facts are the goal; in statistics, facts are the point of departure and identifying a law or pattern is the goal. He insisted that there was no other way to approach social phenomena.

His 'neutral' discourse on the methodology of statistics was actually a fairly obvious attempt to bring about professionalisation, centralisation of competences and decentralisation of implementation. Von Baumhauer made three recommendations. First, work should be organised systematically; specifically, there should be continuous contact between the central level and implementing bodies. Second, detailed documentation should be produced and should include conversions to percentages and references to the legislation in question to facilitate international comparison. Third, probability theory should be applied, as Quetelet had proposed in Florence. He also suggested that greater attention be paid to fluctuations and tendencies, especially in the context of moral statistics. With regard to crime, for example, it was easy enough to make generalisations based on the number of crimes committed, but this was of little use if the circumstances of the crime and the perpetrator were not included in the narrative. He explained that he did not interpret Quetelet's 'propensity for crime' at the level of society as a whole, but always at the level of the individual. It would be absurd to compare a person of poor upbringing and education with 
a cultivated individual and derive from that comparison an average inclination towards criminal behaviour. Slightly bending Quetelet's teachings, Von Baumhauer presented an ambitious programme that was consistent with the trend towards professionalisation seen at previous congresses. However, it was so specific that it was likely to incur opposition.

The programme included a few shorter pieces for the statistical theory section. Johan Marinus Obreen, director of the repository of maps, plans and models and the library at the Department of the Navy, revived the discussion of the graphics method initiated at the Vienna congress in 1857. Johannes Adrianus Boogaard and Lucas Jacob Egeling, both physicians, took up the problem of registering stillbirths, another vintage topic that was tied to the larger issue of registering causes of death, a matter that was regulated by law in the Netherlands (in the Burial Act of 10 April 1869). Von Baumhauer himself addressed the topic of mortality tables and age distribution, a matter of great interest to life insurance companies as well as statisticians and sanitarians. In 1868 he had published an article in the Journal des Economistes proposing a new calculation method that had as much to do with accurate registration as with mathematics.

The conferees were given a chance to respond to aforementioned papers before the congress began. Georg Mayr, the coming man from Bavaria and Friedrich von Hermann's successor, was eager to make his mark. As his later writings would show, Mayr had a predilection for theory. He proposed to define statistics as quantitative 'Massenbeobachtung', or mass observation. In the spirit of Quetelet, he stated that mass observations would be useful only if they were then subjected to logical classification and patterns and laws were identified. Though in theory all human circumstances the world over were potential objects of statistical inquiry, Mayr admitted that the state was usually the best unit within which to conduct statistical research. This implied that statistical laws would apply primarily within national boundaries. At the same time, Mayr acknowledged that the statistics of administrative units such as provinces and municipalities were frequently inadequate when it came to representing 'natural territorial groups'. Mayr did not specify how these natural groups were to be identified, but insisted they could be presented graphically. Another advantage of graphic representations was that they were accessible to a broad public. In Mayr's opinion, maps and diagrams were easier to understand than numbers alone.

Mayr's ideas about statistics as a universal method appeared to correspond well with the overseas territories theme. The topic of colonial statistics was given more attention in the programme overview than in Von Baumhauer's Idées-mères. A provisional committee was formed, comprising former governor-general Ludolf A.J.W. baron Sloet van de Beele, ichthyologist Pieter Bleeker, member of the Council of State Wolter Robert baron van Hoëvell, and Pieter Johannes Veth, a professor of geography and ethnology of the Dutch East Indies - all experts on the Netherlands' overseas territories but none of them known for their statistical talents. Nevertheless, they had big plans. European ideas 
were often applied more systematically and effectively in the colonies than at home, at least initially. According to the committee, colonial statistics should be made to serve the administrative project in the colonies, which consisted in the 'sacred guardianship' of the subjugated peoples. The mother country 'is bound to respect, to a certain degree, the special genius of the subjugated races and, on pain of one day being accused of crimes against humanity, is obliged to justify its dominion by effecting social progress. ${ }^{21}$ Statistics would be an excellent instrument in this pursuit. Furthermore, the committee continued, statistics - in the form of population and tax registers - was already gaining acceptance in Muslim and - to a lesser extent - Hindu regions of Asia. The committee then discussed statistical material pertaining to the colonies that various European powers had produced. In the end, the committee agreed on a set of recommendations regarding the organisation and substance of colonial statistics.

\section{Not on Sunday}

The five proposed themes were accepted by the international statistics community, with one minor addition: it was decided that the fisheries statistics section would also discuss import and export statistics. It was clear from the start that despite Von Baumhauer's call for denationalisation and efficiency - the congress in The Hague would be burdened by national interests (and not least by Dutch interests) and the unpredictable implications of the topics on the agenda. The assembled statisticians would find it difficult to take authoritative decisions on matters like migration policy, fishing quotas and colonial policy. However, Von Baumhauer did succeed in increasing the share of foreign guests to a quarter of the total, thus reversing the decline in international participation.

As was now customary, the official delegates gathered for a meeting prior to the opening of the congress. On the evening of Friday 3 September the gentlemen met at the 'Vereeniging', on the invitation of the minister of the interior and the mayor of The Hague. Deliberations began the next day. In attendance were 47 delegates (including 18 members of the Dutch preparatory commission) from 26 countries (the eight German states were counted separately). They aimed to complete their talks on Saturday, since Anders Nicolai Kiaer of Norway objected to meeting on Sunday on religious grounds.

Quetelet, who was elected chairman, came straight to the point and asked what specific activities had been undertaken to meet the congress's longstanding goal of establishing an international statistics regime. The answer was disappointing. Though the commission set up specifically to address this matter had not convened even once, it was determined that no decision on new appointments would be possible for the time being. Another suggestion aimed at professionalisation and increasing efficiency came from Christian David, the Danish delegate. He proposed convening a post-congress meeting of official representatives to take real decisions. Not surprisingly, there was opposition to this idea. Maestri suggested the congress was taking an 'aristocratic' turn and 
showing a tendency towards 'liberticide. ${ }^{22}$ But his congress in Florence had been exceedingly liberal with respect to the participation of Italians. Most looked favourably on taking action to professionalise the congress. Engel anticipated a conflict and suggested finding out how other congresses structured their decision-making processes. After a second and third ballot, Engel's proposal was adopted. For the rest, the pre-congress dealt with a few motions of order that did not give rise to any lengthy discussion. There was no need to reconvene on Sunday, and the delegates attended a banquet held in their honour at one of the halls of The Hague Zoo. Probably without Kiaer.

The official opening took place in the Ridderzaal on Monday 6 September. Prince Willem of Orange did not attend, but conveyed his apologies through interior minister Fock (in light of what would happen during the royal reception, this is hardly surprising). Fock's opening address was less than inspiring. Predictably, he looked back at a long tradition of statistics in the Low Countries, which - by his timeline - began with a census in 1514. He recalled the work of Jan de Witt, Willem Kersseboom and Nicolaas Struyk, eventually arriving at the nineteenth century, which he described as if statistical research was the country's main occupation. He diverted attention away from the plodding progress of government statistics in the Netherlands by focusing on a few isolated achievements. When he was finished, Vissering took charge of the meeting. The first order of business was to pay tribute to the deceased, including the Bavarian statistician Friedrich von Hermann, Professor Friedrich Wilhelm Schubert of Königsberg and Édouard Ducpétiaux of Belgium, all of whom had attended the congresses from the very beginning. Their generation was dwindling, and this was a great drain on the international statistical movement and contributed to the gradual decline in enthusiasm.

\section{Theory and methodology}

The conferees dispersed for their section meetings immediately after the opening session. The next plenary was not scheduled until after the sections - on Friday afternoon. Some ninety participants, including many official representatives, attended the section on statistics theory. This was the section that people had come for. Von Baumhauer opened the meeting with an homage to Quetelet, who had recently published a new edition of Sur l'homme under the title Physique sociale. Quetelet reciprocated by having Von Baumhauer appointed chairman of the section. Von Baumhauer, who had anticipated that the participants would speak various languages (and did nothing to impede them), appointed minutes secretaries for English, French, German and Italian.

The Belgian Xavier Heuschling, who had always operated in Quetelet's shadow, polarised the debate straight out of the starting block. This was somewhat unconventional and provoked some consternation. Heuschling was worked up about Vissering's stance on the dichotomy between the historical and mathematical schools of thought. He was irritated by the observation 
Vissering made in his paper that the mathematicians had overtaken the historians and perhaps even made them redundant. Heuschling, who was an adherent of the historical school, believed that the mathematical approach was a matter for professors and other learned men, while historical statistics, which he identified with administrative statistics for argument's sake, should be entrusted to statesmen and statisticians in government service.

Quetelet intervened immediately. He was not interested in polarities. 'Statistics can be found everywhere', he said defiantly. He invoked great men like Laplace and Fourier, whom he had known personally. There was no point in having one party create the tables and the other explain and use them. 'One can do no greater harm to statistics than failing to apply a sufficiently scientific approach in the statistical bureaus. ${ }^{23}$

Engel supported this position. He told the section that he had found 180 different definitions of statistics and held up the very case in which he kept them all. In his opinion, there was little point in trying to settle on a single definition. But then he complicated matters by trying to cobble together a definition of sorts. Statistics was, he said, the 'physics of human communities' of which there were four: first, the community of blood, 'the family, the race, the nation'; second, the community of co-existence (the way people lived together), from municipality to the state; third, the community of faith; and finally, the community of common interests - 'society' - though no one knows 'where it begins or ends. ${ }^{24}$ This was not a terribly helpful classification system. Engel concluded that the congress should not take a decision on Vissering's article but should leave the task of defining the limits of statistics to those engaged in the practice. Other prominent statisticians, including Farr, Legoyt and Semenov, concurred, bringing the discussion of Vissering's contribution to a close with the writer's assent.

In the discussion about Von Baumhauer's paper on methodology the same problem returned in a different guise. Again, the debate centred on the relationship between science and public administration, but this time against the backdrop of Von Baumhauer's annoyance about the frequent excess of questions asked in the context of statistical inquiries. This defect could be remedied with some scientific guidance. Fundamentally, everyone agreed with this principle. The question was how to articulate it in a resolution. Attempts to this effect soon sparked a debate on a recurring and sensitive theme: establishing a central commission and determining its remit. In France, Legoyt said, all too often ministries conducted surveys padded with extraneous questions because there was no oversight. Contrary to preconceived notions, centralisation was rare in his country.

According to Engel, where there were central commissions, their performance was mediocre at best. They were no more than an extension of executive power. Rarely was a central commission made up of an efficient mix of scholars and scientists and representatives of the legislative and executive powers. And even those that met this criterion were unable to accomplish much. With the increase in private-sector organisations with a public function, such as railway 
companies, insurers and banks, and the trend towards local autonomy, the only way that statistical societies could achieve anything was by pooling their resources. Clearly, Engel was thinking of the German situation and reintroduced a proposal that he had put forward in Berlin.

Digressions such as these threatened to turn the discussion into a litany of proposals based on national preferences. Engel wanted both centralisation and decentralisation: centralisation in order to harness scientific, political and administrative forces and decentralisation in order to ensure that political and economic realities were taken into account. Others, such as Britain's Lord Houghton, wanted nothing to do with centralisation, even if only in the service of science. The conferees eventually agreed on the formulation of a vague resolution calling for both scientific and administrative interests to be considered when statistical research was being prepared. And once again states that did not already have a central statistical commission were urged to establish one.

The second meeting of the section was also devoted to Von Baumhauer's article. He proposed to count only that which was directly related to the 'physiology of human beings and society'. He defined his terms later in the debate as all knowledge pertaining to the nature of human beings, from the physical, medical, intellectual and moral perspectives, and knowledge of human beings in all conceivable social circumstances. This was a dubious definition. Where precisely should the line be drawn? Quetelet took meteorology as an example. He had famously hypothesised that since temperature had a major influence on disease and death, it should be incorporated into statistics. Alfred Legoyt agreed and informed the section that the Paris Academy of Sciences had recently commissioned a study to determine whether the nearby forest had any effect on the intensity of hailstorms. In Legoyt's opinion, the positive findings of the study underlined the value to meteorology of the statistical method. Engel responded by pointing out that the issue at hand was the methodology of statistics: as a method, statistics was applicable to many things, but it would be wise to limit the scope of statistics as an autonomous science. Von Baumhauer believed that statistics was being confused with its methods. He said that statistics had many methods, of which the numerical approach was just one. His primary goal was to limit the congress agenda to topics that served the interests of public administration, and he felt there was no need for the congress to vote on this.

The discussion moved on to the training of junior statistics officials. In some countries, like Britain and the United States, completed questionnaires were simply sent to a central office where the counting took place. Farr explained that civil servants were paid 'by the piece' as in a factory. In many other countries, lower levels of government were responsible for processing the forms, and the officials working for these agencies needed to have some knowledge of statistics. Engel and Ficker explained that the statistics seminars in Prussia and Austria prepared civil servants for statistical work. But, Engel remarked, universities did not produce statisticians: 'people become statisticians by doing the work. He compared his bureau to a laboratory where people learned hands- 
on. ${ }^{25}$ There was no disagreement about the need to train statistics officials or about the other methodological issues. Nor did the section have any difficulty reaching consensus about the usefulness of multilingual commentary, the incorporation of percentages, the desirability of teaching statistics at various levels or the need to make birth registrations more precise.

A greater degree of controversy was expected during the session held the next day, Wednesday 8 September, which was largely reserved for a discussion of the graphics method. The last discussion on this topic, in Vienna in 1857, had yielded few concrete results. The author of the introductory paper, Johan M. Obreen, opened the debate. He presented a draft resolution and proposed to incorporate maps and diagrams in government statistics reports to improve education in, and simplify, the science of statistics. The contributions to the debate show that statisticians were not yet accustomed to assessing the value of graphical representations, though the British chemist Joseph Priestley had described the advantages precisely one hundred years before - in 1769 . He was perhaps the first to use a timeline to illustrate the rise and fall of empires. In any case, he did his best to show his readers that it was possible to represent time as a line. ${ }^{26}$ One might well assume that this idea caught on quickly and was soon being widely imitated, but apparently it was not that simple. After 1830 graphics started to appear regularly in academic periodicals and books, but even then the method was not widely accepted by statisticians.

The Austrian Adolf Ficker examined further the various ways in which figures could be presented, as if he was proposing a new idea. He rejected the notion of presenting absolute numbers graphically because it would require assigning a unique symbol to each figure, which would only add to the confusion. It made more sense to use relative numbers, which would make it possible to colour in geographical maps and create diagrams. However, it was unclear precisely how that was to be done. For example, what geographical unit could best be used? Ficker's answer was that the size of the geographical unit would be dependent on the level of homogeneity of the conditions underlying the data. This line of reasoning was difficult to follow but apparently required no explanation since everybody seemed to accept that it ensued from Quetelet's theories.

Following Ficker's lead, Engel referred to the wide variety of graphical representations that had been produced since the middle of the century. His thinking on the subject had clearly progressed since 1857 . He remarked that many were no more than pictures. Before the congress could address this matter seriously, attempts would have to be made to standardise the graphics method for statistics. Ficker pointed out that the classification of series of observations posed another problem. Quetelet took up this issue. The objective was to discover the law underlying the observations. Dividing the waist measurements of a large group of people into four groups would yield little information. But examining twenty or thirty groups above and below the average would reveal patterns. This applied not only to body measurements, Quetelet pontificated, but also to human behaviour, such as crime. Despite Quetelet's intervention, the resolutions concerning the graphics method were insubstantial. The congress decided 
that graphs were useful for the popularisation of statistics, and should therefore be added to official statistical documents. As for other matters, it was up to the next congress to take further action.

Next the section addressed the matter of stillbirths, another long-standing issue. It seemed so simple but was in fact extremely complicated because the statisticians wanted to measure something that could not be measured in many countries due to inadequate registration. It would be difficult for statisticians to reach an agreement in this regard because that would require the medical and legal professions as well as local authorities in different countries to come to an understanding. Had the child lived for a time? If the mother died in childbirth, did the child die before or after her? Could it actually be considered a child (or merely a foetus)? These were matters that had a direct bearing on inheritance law and could not be resolved simply because statisticians wanted them to be. Regardless, their deliberations on the subject were impassioned. Several conferees explained how stillbirths were dealt with in their countries. The colourful descriptions revealed a great deal about the role of local government, the clergy, the justice system, physicians and midwives. Had the statisticians forgotten, as they often did, what their field of expertise was, or does this example demonstrate how serious they were in their desire to count - and observe - everything? Legoyt probably would have said the latter. When everyone had had their say and turned their attention to drafting a resolution, he said: 'The real question, the great question, that preoccupies us is this: how do we define a stillbirth?'27 They were back where they had started on this issue.

It appears that the statisticians were looking for common ground on the matter of stillbirths, but unanimity vanished like snow in summer when the issue of mortality tables arose. Various conferees claimed expertise in this area and quarrelled about their use. Quetelet had to assert his authority to end a 'tis'tisn't argument, after which the conferees were able to calmly discuss ideas on the best way to structure a mortality table. The private sector had a major interest in this matter. Life insurance companies were important actors in Great Britain and the United States, and as such were represented at the congress by influential actuaries such as Samuel Brown, Thomas Bond Sprague and Sheppard Homans. However, they were forced to yield to the assembled statisticians, who had little faith in the calculation methods employed by the insurance companies. Statisticians were able to align themselves, but only when they found a common adversary.

The most remarkable moment in the discussion about mortality statistics came when Quetelet admitted openly that he had compiled his comparative mortality tables from the national tables generated by Farr, Berg and others, without accounting for the way in which the original figures had been produced. He had detected regularity and so was not much interested in the method underlying the statistics. Legoyt, Farr and Engel felt that he was going a bit too far. Without contradicting Quetelet directly, they pointed out the marked differences between various countries in the average age of death. As with many other subjects, the way in which European countries registered their populations had 
a direct effect on the accuracy of mortality statistics. But the intractable difference of opinion on the best method of compiling mortality tables was also the result of contrasting arithmetic insights and a lack of criticism with regard to the sources of information.

At the close of the meeting, Engel took the floor. He expressed his wish to evaluate all the congresses, including the gathering in The Hague, before the final plenary session began. He acknowledged that too little had been achieved in terms of standardisation but also identified points of progress, such as the 'large association' of statistics directors that had evolved and the sharp increase in the production of statistical publications. It was imperative to make wise use of this situation. He suggested improving the congress's approach to the idea of international comparative statistics. Each central commission or statistical bureau would choose one subject on which to publish an international statistical report, in French since The Hague congress had proved it was the lingua franca of statistics. The official representatives would need to make separate agreements on this matter.

The official representatives discussed Engel's proposal on Monday 13 September - after the congress ended. He had divided up his project on international and comparative statistics into twenty-five themes and assigned one to each country. Little was accomplished in the way of implementation during the life span of the congress, but the project showed where consensus had been reached: French as the official language, the metric system and the franc as the unit of currency, though conversion would not take place until the final phase of the project. Always one for thoroughness, Engel also suggested that the national statistical bureaux compile a catalogue of statistical works. Speaking for the French, Legoyt and Wolowski insisted it would be an impossible task for French statisticians if they were expected to go back to the start of the international congresses. France, they argued, was not sufficiently centralised and, unlike Germany, it did not have a consolidated book trade catalogue. Others were less pessimistic and thought it would be fairly easy to compile a national statistical bibliography. In the end, the section agreed to publish a joint catalogue in 1870. Though it was beyond the power of the international statistical congress to implement Engel's ideas, they had illuminated the path to a new future. In 1869 the statisticians could not have known that the end of their congress movement was nigh, and that they would soon redirect their efforts to establish the International Statistical Institute in 1885.

Engel introduced the first section's draft resolutions at the plenary on Friday 10 September. He candidly informed the conferees that the section had rejected Vissering's original proposals and Heuschling's alternatives, and decided to propose to the congress that the object and boundaries of statistics were best left to the field to define. He believed that the solution to the factional conflict lay in a new science, 'demology', which would unite all the statistical schools of thought. In essence, this science concerned itself with the goals of every human being on earth. These goals could never be served through individual exploits but only through association and cooperation. In other words, the purpose of 
every human community was to make sure that any individual that was part of it could achieve his aims. The first aim was to be healthy, but thereafter all other aspects of life - physical, intellectual, moral, economic and political - were relevant. At this point, he also addressed the women in the room. In Engel's view, consumption was the measure of well-being and prosperity, and hence of man's purpose on earth. A statistics of consumption - focusing in particular on household expenditure, the province of the woman of the house - was the next great challenge.

Wolowski disagreed with Engel. He thought it was not necessary to invent a new science. He believed that statistics as it was known should be defined, and that it should be defined as a science that made 'social facts' comparable. Statistics was 'decidedly peculiar to the propensities and needs of our time', not only because it was the age of positivism, but also because statistics and democratisation were mutually reinforcing. ${ }^{28}$ With such great differences of opinion among leaders of the congress it was evident that the plenary meeting had no choice but to decide to let the matter of defining statistics rest.

Semenov took the floor to inform the meeting about Von Baumhauer's methodology proposals. He was more concise than Engel and made only a few remarks about each draft resolution, all of which were subsequently adopted. The congress managed to reach agreement on several proposals which, though far from radical, were certainly substantial. They agreed to balance the needs of government, society and science, foster conformity between the various levels of statistical enterprise (in particular, between the envisaged central statistical commissions and the statistical bureaucracies), provide adequate training and instruction for officials, translate essential sections of national statistics publications into German, French or English, incorporate percentage conversions and calculate averages and standard deviations. The decisions concerning the internal organisation of statistics agencies were perhaps difficult to implement since the congress had no power to enforce compliance, but the technical agreements brought standardisation and professionalisation of official statistics a step closer.

\section{Statistics overseas}

The fifth section, the statistics of European overseas territories, drew many Dutch participants, a few Britons, two Spaniards and a Frenchman. It was obvious to everyone that this theme was of particular interest to the host country, but as a courtesy the young Englishman Thomas John Hovell-Thurlow, secretary of the British embassy in The Hague and author of the book The Company and the Crown (Edinburgh 1866), was appointed chairman. The idea of conducting the discussion in English was rejected, also out of courtesy. More problematic was the proposal to appoint former Minister of Colonies Guillaume Louis Baud as vice-chairman, to serve alongside Lieutenant-General Jan van Swieten and Professor Pieter Johannes Veth, who had likewise been appointed vice-chairs. 
The nomination came from Graaf D.C.A. van Hogendorp, who acknowledged that the congress had no political interests but nevertheless his fellow member of the conservative party would have to be given an official function. The section agreed, but it had become clear that the topic of colonial statistics had an unmistakable political dimension. This was true, to a certain degree, of all the congress themes, only on colonial issues it was acceptable to admit it.

Rather than actually debating issues, the members of the section primarily exchanged information. Hovell-Thurlow surprised the section participants by presenting a recent statistical publication by Mooldie Abdool Sutief, an enlightened Muslim, whom he described as a member of the 'Young Bengal' party, which sought to foster the integration of European and cosmopolitan customs, ideas and laws. Several more publications by Europeans or more or less original inhabitants of the colonies were reviewed. The conferees wanted to know how reliable was the information that could be obtained locally. Some were concerned about the religious prejudices of Hindus and Muslims, others believed that - as in Europe - the respondents gave false information for fear of incurring higher taxes. For this reason, it was proposed to add a reliability indication to all colonial statistics reports. With the same scepticism, combined with a thirst for knowledge, they discussed the proposals for creating registries of births, deaths and marriages, and enlisting indigenous locals to help gather statistical data. The participants gave one example after another illustrating how primitive and backward indigenous populations were, but no one knew how to overcome this obstacle other than by paying locals well and showing appropriate respect.

The section attempted to use statistics to evaluate the abolition of slavery, and the participants were especially interested in the increase and decrease of population and production. In other words, they wanted to know whether the ethical decision also made economic sense, or at any rate whether it would work out for the best in the end. Lacking the desired statistical precision, they advanced ideas for acquiring more information about the status and composition of the population. However, the discussion yielded no feasible solutions for their predicament. In the plenary session, the draft resolutions of the fifth section passed without further discussion. On the one hand, the topic of colonial statistics was too far removed from the direct interests of European statisticians to merit the same attention as 'domestic' themes. On the other, the subject had the capacity to satisfy or even fuel the statisticians' urge to promote civilisation and development. They applauded the abolition of slavery, but failed to keep the 'Dutch' theme on the agenda in later years.

The plenary meetings adopted a series of section decisions that are not covered in detail above. These decisions concerned topics such as statistics pertaining to property in mortmain, pro bono legal services, bankruptcy and partnerships limited by shares, cadastral statistics (eighteen pages of questions and tables), the statistics of land credit, national income, taxation, issuing houses, municipal finances, trade and fish catches. As usual, the congress addressed a dazzling array of topics. The Hague congress, like those before it, spoke out in favour of 
implementing the metric system universally and making preparations to introduce a common currency.

The last item of business was to choose the location of the next gathering. The Austrian Ficker designated Switzerland, Russia and Hungary as the prime candidates. Von Baumhauer informed the conferees that during the banquet in Scheveningen the Russian delegate, Semenov, had rhapsodised about the good relations that the Netherlands and Russia had enjoyed since Peter the Great and that he was pleased to support Russia's bid. At the same time, he felt that every country was free to offer itself as a candidate. Victor Balaguer, the Spanish representative, eagerly announced that his country was in the running. Semenov followed suit and officially announced Russia's candidacy. Von Bouschen supported his countryman, resolutely calling upon Europe to do its utmost to finally discover the great unknown. Jules Schreyer, a delegate from the Imperial Free Economic Society in St Petersburg, made Russia's bid more attractive by offering free train journeys from the Prussian border. Though the decision would not be made until later, St Petersburg was the clear favourite.

Von Baumhauer and Vissering achieved in The Hague what they had set out to accomplish: to limit the number of topics, limit the number of participants from the host country, give ample attention to theory and methodology and create a place for colonial statistics. Nevertheless, it was apparent that the international congress needed to do more. There was a pervading sense that no real progress was being made. During the post-congress meeting of official representatives - an organisational innovation that would be discussed as such in St Petersburg - fervent attempts were made to launch a collective project. Tasks were assigned but no guarantees could be given. Some participants, including the Danish delegate Christian David, feared that The Hague would be the last congress. An unfamiliar sentiment had taken possession of the statisticians: doubt.

\section{Notes}

1 Baedeker's Belgien und Holland. Handbuch für Reisende (12th edn, Koblenz and Leipzig 1873), p. 223.

2 F. Allan, De stad 's-Gravenhage en hare geschiedenis (Amsterdam 1859) 5, as cited in H. Schmal, Den Haag of 's-Gravenhage. De $19^{d e}$-eeuwse gordel, een zone gemodelleerd door zand en veen (Utrecht 1995), p. 92.

3 J.H. Furnée, 'Beschaafd vertier. Standen, sekse en de ruimtelijke ontwikkeling van Den Haag, 1850-1890', Tijdschrift voor Sociale Geschiedenis 27 (2001), pp. 1-32.

4 'Uit 's-Gravenhage', Utrechtsch Provinciaal en Stedelijk Dagblad, 7 September 1869 (I would like to thank Jan Hein Furnée for this reference).

5 Nationaal Archief, The Hague, Collectie 426 Familie Fock, 1842-1976, Mémoires over de jaren 1828-1901, inv. no. 4, pp. 441-442.

6 Carel Vosmaer cited in A. van der Woud, Waarheid en karakter. Het debat over de bouwkunst 1840-1900 (Rotterdam 1997), p. 91.

7 'Uit 's-Gravenhage', Utrechtsch Provinciaal en Stedelijk Dagblad, 7 September 1869.

8 'Uit 's-Gravenhage', Utrechtsch Provinciaal en Stedelijk Dagblad, 9 September 1869.

9 M.M. von Baumhauer, Verslag der beraadslagingen op het Poenitentiair Congres, gehouden 
te Frankfort a/M. 28, 29 en 30 September 1846 (Leeuwarden 1846); De landbouwkolonie te Mettray (in Frankrijk), een voorbeeld voor Nederland (Leeuwarden 1847).

10 N. Randeraad, 'The Dutch Path to Statistics (1815-1830)', in P. Klep en I. Stamhuis (eds), The Statistical Mind in a Pre-Statistical Era: The Netherlands, 1750-1850 (Amsterdam 2002), pp. 99-123.

11 M.M. von Baumhauer, 'De statistiek', De Gids 13 (1849) I, 80.

12 Ibid., 86.

13 S. Vissering, 'De statistiek in Nederland', De Gids 13 (1849) II, 17.

14 S. Vissering, Herinneringen, II, Politische vertoogen (Amsterdam 1863), XIV.

15 Nationaal Archief, The Hague, Tweede afdeling, Ministerie van Binnenlandse Zaken, Afdeling statistiek en voorgangers, inv. no. 8, draft resolution 2 January 1869.

16 M.M. von Baumhauer, Idées-mères ou plan motivé d’un programme pour la septième session du congrès international de statistique (The Hague 1868), p. 81.

17 Ibid., p. 11.

18 Ibid., p. 17.

19 S. Vissering, 'Limites de la statistique', Congrès International de Statistique à la Haye, Compterendu des travaux de la septième session. Première partie. Programme (The Hague 1869), p. 13

20 Ibid., p. 18.

21 Ibid., p. 180.

22 Congrès International de Statistique à la Haye, Compte-rendu des travaux de la septième session. Seconde partie (The Hague 1870), p. 10.

23 Ibid., p. 38.

24 Ibid., p. 39.

25 Ibid., p. 55.

26 J. Priestley, A New Chart of History en A Description of a New Chart of History, Containing a View of the Principal Revolutions of Empire that Have Taken Place in the World (London 1769), cited in D.R. Headrick, When Information Came of Age. Technologies of Knowledge in the Age of Reason and Revolution 1750-1850 (Oxford 2000), pp. 124-125.

27 Compte-rendu des travaux de la septième session, Seconde partie, p. 88.

28 Ibid., p. 438. 